\title{
Kernos
}

Revue internationale et pluridisciplinaire de religion grecque antique

3| 1990

Varia

\section{Oracle-Mongers in Peisistratid Athens}

\section{H. Alan Shapiro}

\section{CpenEdition}

\section{Journals}

\section{Electronic version}

URL: http://journals.openedition.org/kernos/1004

DOI: $10.4000 /$ kernos. 1004

ISSN: 2034-7871

\section{Publisher}

Centre international d'étude de la religion grecque antique

Printed version

Date of publication: 1 January 1990

ISSN: 0776-3824

\section{Electronic reference}

H. Alan Shapiro, «Oracle-Mongers in Peisistratid Athens », Kernos [Online], 3 | 1990, Online since 19 April 2011, connection on 02 May 2019. URL : http://journals.openedition.org/kernos/1004 ; DOI : 10.4000/kernos.1004 


\section{ORACLE-MONGERS IN PEISISTRATID ATHENS*}

Near the beginning of Book 7 of Herodotos' Histories, we hear about a remarkable collocation of people living at the Persian court in Susa (VII, 6). The year is 486 B.C., Xerxes has just succeeded to the Persian throne, and he is under pressure to undertake a new expedition against Greece, after the failure of Datis and Artaphernes, sent out in 490 by Xerxes' father Darius, at Marathon. Among those urging him on are ambassadors from the ruling dynasty of Thessaly, the Aleuadai, who would later be counted as infamous Medizers during the invasion of 480 . Then there was Hippias, son of the Athenian Tyrant Peisistratos and later Tyrant himself. He had been driven out of Athens over twenty years before, in 510, had fled first to Thessaly (where he no doubt was received by the Aleuadai), and eventually made his way to Persia. We do not know his exact year of birth, but he could scarcely have been less than 80 by now ${ }^{1} ; 60$ years before, as a young man, he had accompanied his father's third and most successful seizure of power in Athens ${ }^{2}$. And now he still cherished hopes of returning in triumph to his native city. A few years earlier, in 490, he had gotten as far as Marathon (Herodotos, VI, 107), with the first Persian invasion, but no further. But like his father, who was twice exiled and twice returned to power, he evidently was a man of considerable perseverance.

We hear very little from Herodotos about Hippias at the Persian court beyond the fact of his presence there, but much more about another Greek, Demaratos, the exiled king of Sparta. He figures prominently as a trusted (though not always heeded) adviser to Xerxes both before and

* I would like to thank all the organizers of the Liège Colloquium, especially Prof. A. Motte, for their hospitality. I am also grateful to Mme. A. Verbanck-Piérard for the invitation to join C.E.R.G.A. and many other kindnesses. This paper is an expanded version of the one I presented in Liège and represents, with minor changes, the text of a lecture given to the American School of Classical Studies, in New York, 5 April, 1989. I thank Catherine Vanderpool for the invitation to speak on that occasion.

1 On the birth years of Peisistratos and his sons, see M.E. WHITE, Hippias and the Athenian Archon List, in Polis and Imperium, FS E.T. Salmon, Toronto, 1974, p. 81-95; J.K. DAvies, Athenian Propertied Families, Oxford, 1971, p. 445-447.

2 For the date of the Battle of Pallene and Peisistratos' third tyranny, see P.J. RHoDes, Peisistratid Chronology Again, in Phœnix, 30 (1976), p. 219-233. 
during the invasion of 480 . Hippias and Demaratos must have known each other well during these days of idle luxury at the court.

But perhaps the most interesting member of this small group of Greek exiles at Susa - certainly the best raconteur - was one Onomakritos, an Athenian. Herodotos introduces this man as a chresmologos (VII, 6) literally a "gatherer of oracles," though I retain the Victorian translation "oracle-monger» ${ }^{3}$. Herodotos also describes Onomakritos as the diathetes chresmon ton Mousaiou - that is, the man who arranged the oracles of Mousaios 4 . Onomakritos had once been very close with Hippias and his family back in Athens, then had a falling out, but now, together in Susa, they had been reconciled. They were, after all, both exiled Athenians in Persia. Besides, the oracle-monger was extremely useful to Hippias at the Persian court, for the superstitious Xerxes was easily influenced, and Onomakritos chose his oracles carefully, relating only those that predicted a great victory for Xerxes, should he cross the Hellespont and invade Greece.

The reason for the falling out between Onomakritos and his Peisistratid patrons is also recounted by Herodotos (VII, 6). It seems that one day Onomakritos was caught in the act of forging an oracle and inserting it into the collection of oracles of Mousaios that he had made for the Athenian Tyrants. For this offense, Hipparchos, the younger brother of Hippias, who functioned as a sort of informal Minister of Culture during his brother's rule, banished Onomakritos from Athens. His "crime" is a little difficult to fathom, for Mousaios was a legendary singer and prophet, akin to Orpheus, thus every oracle ascribed to him must have been made up by someone else, presumably by chresmologues like Onomakritos. How, then, did some oracles receive the imprimatur "Genuine Mousaios", while others were regarded as forgeries ? Luckily, Herodotos records the gist of the forged oracle, and we can infer from this that it was the content of the oracle, rather than the act of forgery, that so enraged the Tyrants. The oracle said that the islands around Lemnos, in the North Aegean, would disappear under the sea. The Peisistratids had designs on the whole Hellespont region, including Lemnos and parts of the mainland opposite. A few years later, in 513, the oracle came true - not literally, but in the more indirect way in which most Greek oracles came true, the way the Peisistratids must have

3 On the terms Chresmologos and mantis, see J.H. OLIVER, Athenian Expounders of the Sacral and Ancestral Law, Baltimore, 1950, p. 6-11.

4 On Mousaios, see most recently M.L. WEST, The Orphic Poems, Oxford, 1983, p. 39-41. 
feared most : a Persian general, Otanes, captured Lemnos and the neighboring island of Imbros for Persia. Hence, as far as the Greeks were concerned, they might as well have sunk beneath the sea ${ }^{5}$. Even today the oracle has not fully lost its power, for the island of Imbros has disappeared from most maps of Greece : it belongs to the Turks.

At times in Herodotos' portrayal of him, Xerxes seems a bit of a buffoon in his gullibility and belief in portents and dreams (e.g. Herodotos, VII, 15). But it is likely that the Greeks of this time were no less superstitious, and in Athens in particular, the influence and power of oracles and the men who dealt in oracles are especially striking.

The family of Peisistratos offers some good examples. The elder Tyrant's extraordinary career was foretold even before his birth by a strange portent (Herodotos, I, 59). His father Hippokrates was at Olympia performing a sacrifice. Before he had lit the fire beneath the bronze cauldrons, they boiled up and bubbled over. At this, Chilon of Sparta, a famous seer and one of the Seven Sages, warned Hippokrates against having children, or, if he already had any, against raising them - a warning that went unheeded.

Years later, at a crucial juncture in his career, a chance encounter with an oracle-monger helped change the course of Peisistratos' life. He had first come to power in a coup d'état in 560 B.C., only to be driven out of Athens by his political enemies within a year or two. A realignment of political liaisons and a strategic marriage brought him back to power, but this shaky alliance soon collapsed, leaving Peisistratos and two young sons once again in exile from Athens. This time Peisistratos bided his time, struck it rich with gold mines up in Thrace, and collected an army of mercenaries and friends before planning his return to Athens after an absence of almost ten years. The year was now 546 B.C. Gathering his men on the island of Euboea, he crossed to the coast of Attika at Marathon (just as the Persians would do in 490) and made his way toward Athens. The Athenians, meanwhile, raised an army against him, which came out as far as the town of Pallene in East Central Attika. It was at this moment that Pesisitratos came upon one Amphilytos, an itinerant chresmologue, originally from Akarnania in

5 On this episode, see M.P. NILsson, Cults, Myths, Oracles and Politics in Ancient Greece, Lund, 1951, p. 132; ID., Political Propaganda in Sixth Century Athens, in Studies Presented to David M. Robinson, II, St Louis, 1953, p. 745. 
Western Greece ${ }^{6}$. Amphilytos pronounced this oracle (preserved for us by Herodotos) :

The cast has been thrown, the net has been spread,

In the moonlit night the tunny-fish shall come for the taking.

Peisistratos immediately recognized the oracle's meaning for him : the Athenian army were off guard, ready to be caught unawares like so many fish in a net ${ }^{7}$. He attacked at once. The Athenians had just finished their lunch and were relaxing. Some, says Herodotos, were playing dice ${ }^{8}$. They surrendered without a fight, and Peisistratos seized power for what would become eighteen years of mostly peaceful and prosperous - if nonetheless tyrannical - rule.

The encounter with Amphilytos will surely have bolstered Peisistratos' faith in oracle-mongers, and from this point on, both he and his sons maintained a keen interest in oracles. Two late antique sources claim that Peisistratos was given the nickname Bakis ${ }^{9}$. Bakis was the name of a mantis, or seer, probably legendary, under whose name many oracles circulated, from the Archaic period down into the fourth century ${ }^{10}$. He is mentioned, for example, by Aristophanes (Knights, 123-124; Birds, 962), and Plato mentions him in the same breath with the Sibyl (later made famous by Vergil but known to Greek authors as early as the sixth century) ${ }^{11}$. As a nickname, Bakis must have implied that Peisistratos had more than a casual interest in oracles. In fact, he made a collection of oracles, which he kept on the Akropolis, and this was maintained and added to after his death by his two sons. In 510, Hippias, who is described by Herodotos as "well-versed in oracles» (Herodotos, V, 90), was overthrown and fled Athens in such haste that he left the precious oracle collection behind. It was discovered by the Spartan King Kleomenes, who brought it home to Sparta.

Where, we may ask, did all these oracles come from, and how did they get into the Tyrants' collection? Of course the main source of

6 On Amphylitos see [Plato], Theages, 124d, who links him with Bakis and the Sibyl.

7 I have speculated that the reference to tuna in this oracle may find indirect reflection in some vase-paintings, in Poseidon and the Tuna, in AC, 58 (1989).

8 On this detail, see J. BOARDMAN, Exekias, in AJA, 82 (1978), p. 24.

9 Sch. ARISTOPHANES, Peace, 1071; Suda, s.v. Bakis.

10 On Bakis, see I. TRENCSÉnYI-WALDAPFEL, Die Weissagungen des Bakis, in Untersuchungen zur Religionsgeschichte, Amsterdam, 1966, p. 232-250.

11 Cf. supra n. 7 and, on the Sibyl, W. BURKERT, Greek Religion, trans. J. Raffan, Cambridge, Mass., 1985, p. 117. 
oracles in Greece was Delphi, and many could have originated there. It is often alleged that the Delphic oracle would not have anything to do with Peisistratos or his family, because it was in the employ or under the influence of his arch-rivals the Alkmeonidai. But the evidence is not so clear cut. One of Peisistratos' first acts in his third tyranny (ca 545) was to purify the holy island of Delos by digging up all the graves within sight of the Temple of Apollo (Thucydides, III, 104, 1). He undertook this purification, says Herodotos (I, 64), in response to an oracle, and it would be logical to think that that oracle came from Apollo at Delphi. Others in the collection could have come from other oracular shrines, like Dodona, and some were attributed to famous seers like Orpheus, Mousaios, and Bakis - whoever actually wrote them. The sons of Peisistratos hired Onomakritos evidently to be curator of their oracle collection, though he engaged in other activities while in Athens too, as we shall see.

If there was an oracle that accompanied Peisistratos to his greatest triumph, in 546, there was also, not surprisingly, an oracle predicting Hippias' ignominious fall from power. After his brother Hipparchos' murder in 514 at the hands of Harmodius and Aristogeiton, Hippias, afraid for his life, became harsh and ruthless, for the first time truly living up to the name of Tyrant. He fortified a hill known as Mounychia, overlooking the Piraeus, just in case. In the event, his overthrow was so sudden that he never had time to use the fortress, and instead fled Attika altogether (ending up at the Persian court). But the Athenians remembered an old prophesy attributed to one Epimenides, a wise man from Crete said to have come to Athens in the time of Solon (that is, almost a hundred years earlier). When shown Mounychia hill, Epimenides was said to have exclaimed, "Man is indeed blind to the future. For if the Athenians knew what mischief this place will bring the city, they would eat it with their own teeth.»

Epimenides should join the company of manteis and prophets active in Athens that we have been gathering, and, to judge from the wealth of ancient references to him, he was one of the most beloved ${ }^{12}$. Epimenides presents the historian with two particularly thorny problems. First, does he belong with the legendary prophets, like Mousaios and Bakis, or is he a historical figure, like Onomakritos and Amphilytos ? And, if the latter, when exactly was he in Athens ? The story about Mounychia, placing Epimenides in Athens in the time of Solon, is told by both

12 The sources are collected by H. DIELs, Über Epimenides von Kreta, SBBerlin, 1891; H. Demoulin, Épiménide de Crète, Brussels, 1901. Cf. LATTE, in RE, XVIII, 1, 850 sq. 
Plutarch (Solon, 12, 10) and Diogenes Laertius (I, 114-115). But Plato, who would seem at first glance more reliable than either of these because closer in time to the events, puts him in Athens «about ten years before the Persian Wars," thus about 500 B.C. (Laws, 642d). Though all the sources talk about Epimenides as a historical person, it is precisely this 100-year discrepancy that casts doubt on whether he was a real person at all. Nor do the stories that, as a child tending the sheep, he fell asleep for 57 years, à la Rip Van Winkle, then lived to 157, inspire confidence in his historicity.

Yet there is one archaeological monument - not, unfortunately, preserved - that makes the search for the real Epimenides particularly intriguing. Pausanias (I, 14, 4), in his tour of the Athenian Agora in the second century A.D. ${ }^{13}$, visited the sanctuary of Demeter and Kore, which was a kind of "branch" of the principle cult of Demeter at Eleusis and, in fact, was known officially as to Eleusinion to en astei (the Eleusinion in the city). Pausanias had intended to describe this sanctuary and its contents, but a vision he had in a dream prevented him from doing so. We know, of course, that it was strictly forbidden to reveal what went on in the Mysteries at Eleusis (as both Aeschylus and Alcibiades discovered, to their pain), and apparently Pausanias must have believed that this prohibition applied to the Eleusinion in Athens as well (even though, so far as we know, no secret rites of initiation went on there).

Thanks in part to Pausanias' reticence, the Eleusinion has remained one of the more elusive sanctuaries in the area of the ancient Agora. Its location was identified with reasonable certainty in the early years of the American Agora Excavations : some distance outside and above the Agora proper, on the Southeastern slope of the Akropolis, and alongside the Panathenaic Way ${ }^{14}$. Pausanias describes the sanctuary only as "above the Enneakrounos," the most famous of Athens' public fountain houses, and this has been identified by the excavators with the fountain house at the Southeast corner of the Agora. So far the foundations of one temple, of the early fifth century, have been found in the sanctuary. But since Pausanias implies that there were two temples

13 See E. Vanderpool, The Route of Pausanias in the Athenian Agora, in Hesperia, 18 (1949), p. 128-137.

14 H.A. Thompsom and R.E. WyCherley, Agora XIV : The Agora of Athens, Princeton, 1972, p. 150-155; J. TRAVLOS, Pictorial Dictionary of Ancient Athens, New York, 1971, p. 198-203. 
in the Eleusinion, one of Demeter and Kore and one of Triptolemos, it is hard to say which one this is.

Instead of describing the sanctuary in detail, he makes only one comment, about some monuments that stood out in the open and so could not possibly be considered secret : "In the forecourt of this temple [presumably the Temple of Triptolemos, which he has earlier mentioned], where the statue of Triptolemos is, there stands a bronze ox, as if being led to sacrifice, and also a seated statue of Epimenides of Knossos, who they say went into a cave out in the country and slept». Since Epimenides was credited, among other things, with purifying Athens at a time of religious pollution (having to do with the murder of Kylon and his followers by the Alkmeonidai; Diogenes Laertius, I, 10, 110 ), it is not implausible to find a statue of him dedicated at a prominent spot in the city. But it is the setting and the company he keeps that arouse curiosity. According to some sources, when Epimenides came to Athens he took the name Bouzyges (Servius, on Georgics, I, 19), a legendary Attic hero who was supposed to have first yoked oxen to the plow ${ }^{15}$. Two Attic vase-paintings show Bouzyges and his plow, one with Demeter and the Attic King Kekrops watching ${ }^{16}$. The pairing of the statue of Epimenides with a bronze ox now makes sense, if we assume that Pausanias has also conflated the Cretan wise man with the Attic agricultural hero. This in turn explains why both were in front of the Temple of Triptolemos, the agricultural hero worshipped together with Demeter and Kore both in Eleusis and in Athens ${ }^{17}$. In Athens, at least, Triptolemos was the hero who, at Demeter's behest, instructed the farmers of Attika in the arts of agriculture, particularly the sowing of seeds - a story documented by dozens of vase-paintings ${ }^{18}$. The sower

The earliest preserved mention of Bouzyges occurs, interestingly, in a fragment of LASOS OF HERMIONE, the poet who worked for the Peisistratids alongside ONOMAKRITOS, in Athens. Cf. LIMC, III (1986), p. 153-155, s.v. Bouzyges (C. BERARD) and, on LASOS, infra n. 22.

16 Red-figure bell-krater, Harvard 1960.345; BEAZLEY, $A R V 2,1115$, 30; E. SIMON, Festivals of Attica, Madison, 1983, pl. 7, 2 and p. 21. The other, much earlier vase is a black-figure cup, London 1906.12-15.1; BEAZLEY, $A B V, 90,7$; B. AshMOLE, Kalligeneia and Hieros Arotos, in JHS, 66 (1946), p. 8-10.

17 G. SCHWARz, Triptolemos : Ikonographie einer Agrar- und Mysteriengottheit, Graz, 1987.

18 SchWARZ (supra n. 18); A. and I. RAUBITSCHEK, The Mission of Triptolemos, in Studies in Athenian Architecture, Sculpture and Topography, FS H.A. Thompson, 1982 (Hesperia Suppl., 20), p. 109-117. 
and the plowman thus, appropriately, stood side by side in the sanctuary devoted to the goddess of the grain.

We seem to have strayed far from oracles and oracle-mongers, but the mention of Triptolemos will bring us back to some familiar names. Pausanias has a long digression about Triptolemos (I, 14, 2-3), in which he tries - without much success - to sort out the tangled stories about him, especially his parentage. Interestingly, one of the several genealogies is ascribed to Mousaios and one to Orpheus. But in both instances Pausanias is skeptical about the attribution, and elsewhere he claims that a verse attributed to Mousaios was really written by none other than Onomakritos, the Athenian oracle-monger (I, 22,7). No doubt the story of his forged Mousaios oracle made Onomakritos a target of wider suspicions.

What is the implication of all this ? First and foremost, that both the sources of oracles, like Orpheus and Mousaios, and their interpreters, like Onomakritos, when they were not busy practising their mantic arts, were most deeply involved with one particular cult, that of Demeter. The ancient sources refer again and again to this involvement. The cults promoted by the Tyrants, such as Demeter's (but also that of Dionysos) entailed rituals and festivals at which hymns and other verses were recited or sung, and it seems that oracle-mongers like Onomakritos, when they were not occupied with their oracles, doubled as writers of religious poetry. Indeed it is noteworthy that virtually all the oracles that Herodotos records are in neat dactylic hexameters. In Pausanias' view there was only one genuine work of Mousaios, and it is a Hymn to Demeter (I, 22, 7). Even that one could well be by Onomakritos, since the date Pausanias implies for the hymn coincides with Onomakritos' activity in Athens and Mousaios, as we have seen, is a legendary figure ${ }^{19}$. As early as Euripides' time (and perhaps earlier), Orpheus was considered the founder of the Eleusinian Mysteries (Euripides, Rhesos, 943 sq.; cf. Aristophanes, Frogs, 1044) ${ }^{20}$. Onomakritos wrote a poem about the ancient cult of Demeter and Kore at Lykosoura in Arkadia (Pausanias, VIII, 31, 3), and his colleague in Athens, Lasos of Hermione (the one who exposed Onomakritos' forgery), composed a Hymn to Demeter that was famous because it was written entirely

19 This hymn was commissioned by the Lykomedai; on this family, see the paper by I. LOUCAS in this volume.

20 See F. GRAF, Eleusis und die orphische Dichtung Athens in vorhellenistischer Zeit, Berlin, 1974, p. 22-39; ID., Orpheus : a Poet among Men, in Interpretations of Greek Mythology, ed. J. BREMMER, Totowa, NJ 1986, p. 80-106. 
without the letter sigma ${ }^{21}$. The central role of Triptolemos in the Attic cult of Demeter, even though he is barely mentioned in the early Homeric Hymn to Demeter, has been ascribed (I think rightly) to the influence of sixth-century poets like Onomakritos and others in the Orphic tradition ${ }^{22}$. One such tradition must lie behind the remarkable vase-painting in Reggio, probably by Exekias, the only Archaic depiction of Triptolemos where he is not dispensing his agricultural gifts $^{23}$. Rather, he is with Herakles, Athena, Demeter, and a god labelled Ploutodotas, an Orphic epithet of Zeus. I take this scene to represent the founding of the Lesser Mysteries in Athens, where Herakles was initiated before he could be initiated at Eleusis ${ }^{24}$.

What, then, was the reason for the intense interest in the cult of Demeter on the part of chresmologues and manteis ? - apart from the obvious appeal of a mystery cult with secret initiation rituals. I think the answer lies primarily in the story that forms the central dogma, as it were, of Eleusinian religion, the story of the Rape of Persephone by the god Hades, her stay in the Underworld as her mother searched the earth for her, and her return to the earth and the division of the agricultural year that resulted. The idea of the nekyia - the descent to the Underworld and return - fascinated the Greeks from early times. Only a privileged few heroes had this experience : Odysseus, when he went to consult the seer Teiresias; Herakles, when he fetched the dog Cerberus as his final Labor; Theseus, when he and Perithoos rashly tried to abduct Persephone and got stuck down there and had to be rescued by Herakles; and, perhaps most famous in later tradition, Orpheus himself, when he tried in vain to recover his beloved Eurydice. Whether for this reason or others, Orphic poetry was often concerned with death and afterlife and the Underworld; and the Mysteries of Demeter, with their promise of a happy afterlife for the initiated, offered a natural association. So, for example, Socrates at his trial names Triptolemos as one of the judges in Hades, along with Minos, Rhadamanthys, and Aeacus (Plato, Apology, 41a), and fourth-century vases from Apulia depict Triptolemos in this

21 Athen., IX, 467a; X, 455c; XIV, 624e. On LAsos, see G. Privitera, Laso di Ermione, Rome, 1965.

22 Schwarz (supra n. 18), p. 237; N.J. RICHARDSON, The Homeric Hymn to Demeter, Oxford, 1974, p. 75.

23 Amphora, Reggio 4001; Beazley, ABV, 147, 6; G. PRocopio, in ArchClass, 4 (1952), p. 153-157 and pl. 30-32.

24 I have discussed this scene in detail in Art and Cult under the Tyrants in Athens, Mainz, 1989, p. 78-80. Cf. the comments of J. BOARDMAN, Heracles, Peisistratos and Eleusis, in JHS, 95 (1975). 
guise 25 . Herakles' nekyia was tied into the cult of Demeter by the invention (probably in the sixth century) of the story that he was initiated at Eleusis, and this enabled him to undertake the capture of Cerberus ${ }^{26}$. A poem recounting all this, a «Katabasis of Herakles,» was written in Athens in the mid-sixth century, and bits of it have been discovered on papyrus. Hugh Lloyd-Jones suggested it could have circulated under the name of Mousaios ${ }^{27}$. But perhaps the same poem also contained a version of these familiar verses from Odyssey, Book 11, which the Scholiast claims were inserted by Onomakritos (Odysseus is describing his visit to the Underworld) :

Then I noticed mighty Herakles,

His phantom, for he himself, among the immortal gods, enjoys the feast and has Hebe as his wife,

She of the fair ankles, daughter of great Zeus and Hera ${ }^{28 .}$

Apotheosis, like the descent to Hades, would have appealed to the Orphics.

In 486 B.C., when Onomakritos and Hippias were sitting in Susa, plotting a return to Athens that would never happen, the repute of oraclemongers in their native city may already have been in decline. One has to wonder how much the devious Onomakritos might have contributed to the later disrepute of his profession. As in all times of crisis, during the Persian Wars oracles flew about particularly thick and fast. Herodotos, himself a great believer in oracles, tried hard to support their credibility by insisting that the great victory at Salamis fulfilled several oracles of Bakis, Mousaios, and another chresmologue, otherwise unattested, named Lysistratos (VIII, 96, 2) - without telling us just what these oracles said ${ }^{29}$. And of course that same victory would not have happened without the famous oracle from Delphi about "Divine Salamis" and the wooden walls, and Themistokles' brilliant interpretation of it to mean that the Athenians should trust to their wooden ships and engage the Persian enemy off Salamis (Herodotos, VII, 142-143).

25 E.g. the fragment Karlsruhe B1549; CVA (Karlsruhe 2) pl. 64,7.

26 Cf. BOARDMAN (supra n. 24), p. 8-9.

27 Heracles at Eleusis :P. Oxy 2622 and P.S. 1.1391, in Maia 19 (1967), p. 206-229.

28 On Onomakritos and the sixth century Athenian recension of Homer, see R. BöHME, Peisistratos und seine homerische Dichter, Bern, 1983; WEST (supra n. 5), p. 249.

29 See R. CraHay, La littérature oraculaire chez Hérodote, Paris, 1956. 
Yet in spite of this timely advice, the reputation of Delphi, and of oracles in general, was rather tarnished by Apollo's earlier pronouncements, which consistently predicted a Persian victory in Greece $^{30}$. This major gaffe may have been the result not so much of a clouded crystal ball, an off day for the Pythia, or a Persian bribe, but simply of a realistic (though, as it turned out, mistaken) assessment by the Delphic priests of the overwhelming military advantage of the Persians.

In any case, the status of oracles and oracle-mongers in Athenian society seems never to have recovered fully from this blow. At the outbreak of the Peloponnesian War, not surprisingly, Thucydides reports that many chresmologues were going around chanting oracles, not only in the cities that were about to go to war, but all over Greece (II, 8, 2). But Aristophanes, who provides the best mirror of Athenian mores in this period, paints a rather unflattering picture of the oracle-monger as a charlatan whose verses are obscure, his principal motivation greed. In the Birds, an unnamed chresmologos accosts Peisthetairos, the founder of Cloudcukooland, with verses purportedly of Bakis (962-970). These specify that the prophet is to be given a clean cloak, new sandals, and some choice morsels of food. Instead the chresmologue is reviled as a cheat and imposter and receives from the protagonist only a round beating. This is Artistophanes the cynical observer speaking, who loved to skewer hypocrisy. But no doubt many soothsayers and fortune-tellers and chresmologues profited handsomely from devoted clients in late fifth-century Athens. The same could be said of their descendants in our own day, when fortune-tellers and astrologers have taken the place of Greek chresmologues.

Stevens Institute of Technology

H. Alan SHAPIRO

Department of Humanities

Castle Point on the Hudson

Hoboken, New Jersey 07030

U.S.A.

30 J. Fontenrose, The Delphic Oracle, Berkeley, 1978; BuRKER'T (supra n. 11), p. 116. 